\title{
Nature Park as a Resource for Nature Based Tourism
}

\author{
Agita Livina, Professor ${ }^{1}$, Mahender Reddy, Professor Assistant ${ }^{2}$ \\ ${ }^{1}$ Institute of Social, Economic and Humanities Research of Vidzeme University of Applied Sciences \\ Cesu Street 4, Valmiera LV-4200 LATVIA \\ Agita.Livina@va.lv http://hespi.lv/en \\ ${ }^{2}$ National Institute of Tourism and Hospitality Management \\ Telecom Nagar, Gachibowli, Hyderabad, INDIA -500032 \\ mahendergavinolla@gmail.comwww.nithm.ac.in
}

\begin{abstract}
The aim of this comparative article is to show the differences between the visitors' purposes and habits in two national parks: Gauja National Park (GNP) in Latvia and Kasu Bramhananda Reddy National Park (KBR) in Hyderabad, Telangana in India. As well as that, the article aims at highlighting differences in the functional use of the national parks and their locations in the urban and rural context. The study has used the secondary data analysis, such as the analysis and overview of the literature, previously conducted studies and information sources, visitors' surveys in the national parks, and the exploration of the park areas for the evaluation of tourism infrastructure. The results of the study show distinct differences in the national park functions, target groups and their needs. The main target group in KBR is local inhabitants of the million city, and the national park basically fulfils the function of a city park-it is a green area for passive and active (jogging) leisure rather than a nature tourism offer. GNP has three target groups: the local population for a healthy leisure time, domestic visitors and foreign visitors for nature and cultural purposes. Thus, KBR status as a national park is misleading for the international traveller. In the future research it is planned to compare GNP with a national park in India which is located outside the urban environment, carrying out an in-depth study of visitors' opinion on the purpose and elements of infrastructure.
\end{abstract}

Keywords: nature based tourism; purpose; motivation; national parks; infrastructure.

\section{INTRODUCTION}

There are different types of tourism; some are very closely connected with national parks. Parks play a major role in leisure and recreation of the population of urban areas. According to the World Health Statistics 2014, 54\% of the world's population live in urban areas [7]. In the last almost 50 years there has been an increase in urban population of $20 \%$ with a tendency and forecast to continue the growth of more than $1 \%$ per year in the future. There are distinct differences among countries regarding the urban and rural population; the urban population in India is $31 \%$, in Latvia $68 \%$, in Malawi $16 \%$, in Nepal 17\%, in Nauru and Monaco $100 \%$, in Iceland $94 \%$ [8]. National parks are relevant for nature tourism and eco-tourism. However, these data show that national parks are significant also for the domestic tourism and recreation with the main purpose of leisure for the population in urban areas with a high level of population concentration. In addition, these areas are generating potential for the international tourism.
The World Tourism Organisation of United Nations (UNWTO) reported that the number of international tourists has seen a steady growth from 25 million in 1950 to 1,235 million in 2016. The UNWTO has predicted it to reach 1.8 billion by 2030 according to the newly released long-term forecast called Tourism Towards 2030 by the UNWTO [22]. The fact that $53 \%$ of the total trips in 2016 were for leisure, recreation and holidays indicates the continuing importance of the proper management of recreational areas, especially of wilderness and parks [10], [22]. It points to the necessity of sustainable tourism planning and management, particularly in national parks.

According to the Guidelines of the International Union for Conservation of Nature (IUCN), a protected area is defined as "a clearly defined geographical space, recognized, dedicated and managed, through legal or other effective means, to achieve the long-term conservation of nature with associated ecosystem services and cultural values". The term covers a wide variety of designated areas, namely wilderness areas, nature reserves, national 
parks or protected landscapes that can be land, inland, coastal, water or marine areas, or their combination. There are different aims, objectives and restrictions to every IUCN protection category. However, all categories have the common principle of conserving biodiversity and maintaining diversity of landscape or habitat [20].

National parks are among the major resources and attractions for the nature based tourism, and the national park label is the most well-known for tourists and visitors from the categories of protected areas [14], [17], [15]. Nature based tourism is an important segment of the international and domestic tourism industry throughout the world, which has been expanding rapidly over the past decades, and further growth is expected in the future [12]. Nature based tourism is expected to have a continuous growth from an estimated $7 \%$ of the global tourism in 2007 to as much as $25 \%$ by 2020 [2]. Nature based tourism is the fastest growing branch of tourism both in Europe and in India as the demand for it has been rising at a steady pace [18]. Tourism in national parks contributes towards the conservation of flora and fauna as well as provides local livelihoods, since it is often promoted as a win-win scenario in which tourists have an enjoyable experience [1] - [3].

Natural heritage has two forms: the tangible, which is mostly known as the geological forms (cliffs, stones), flora, fauna, ecological processes, and the intangible [16]. In times when the number of visitors in national parks is increasing throughout the world, the most significant task is to develop and strengthen the intangible natural heritage by providing services and information posters about the symbiosis of humans and nature. Hall shows broader dimensions of the impacts of tourism, including socio-environmental impacts i.e. landscape change [4]. Landscape is the backbone element in the protected areas in Latvia, also Gauja National Park. On the contrary, in national parks in India the most crucial task is to protect and save specific species of fauna, for example the tiger (Panthera tigris). Goosling and Hall have made an overview of the scale of tourism analysis clearly showing that the landscape analysis has not been studied sufficiently on a broader scale than the regional [4].

According to Weaver et al [5], there are various types of tourism activities in the nature based tourism. These activities are different from other types of tourism because of the position of the natural environment, or for the reason it is completely based on the natural element of the place. Davidson [16] has mentioned characteristics and attributes of natural landscapes, for example the "natural quit". The nature based tourism offers a wide variety of activities for tourists such as fitness, viewing, snow and ice related, outdoor and also adventure activities like hiking, mountain climbing, rock climbing, rafting, boating, swimming, kayaking, wildlife watching, bird watching, sightseeing, camping, skiing, airballooning, etc. [9].

\section{MATERIALS AND METHODS}

For conducting the research the authors used semi-structured interviews from different organizations in India and Latvia, and visitors' surveys mainly in Gauja National Park (GNP) in Latvia, but in a sample volume also in Kasu Bramhananda Reddy National Park (KBR) in India. Visitors' survey in the GNP was conducted between June and October 2015 in the Latvian and English languages. The visitors' survey could be interpreted as a structured interview - a qualitative method based on a large number of questions. The total number of respondents in GNP was $n=147$, including $74 \%$ local residents and $26 \%$ foreign visitors. The respondents were surveyed in different locations of GNP objects, transport hubs, choosing different days of the week and weather conditions, times of the day and special public events. A sample visitor survey $(n=15)$ was conducted in KBR in February 2014.

For conclusions data triangulation and observation methods were used in both countries by both authors. As well as that, the review of literature studies was carried out. The main limitation of the research is that the statistical data of the number of visitors in both national parks is not available and collected.

\section{Background information on the selected national parks}

The authors have chosen two case studies, one from Latvia and the other from Hyderabad, India. The article explores different aspects of tourism, particularly tourism resources, activities, nature and type of visitors of the protected areas: the primary case study is Gauja National Park in Latvia; the secondary or complementary case study is Kasu Bramhananda Reddy National Park, Hyderabad, Telangana in India. The essential strategy behind selecting both parks is that both national parks are located in close proximity to and/or in the city, and the visitor activities are also similar in both parks. The objective of the paper is to find out the difference between two national parks in Latvia and India in terms of tourism resources, motivation of visitors, activities in the parks, and challenges and issues relating to tourism management.

Latvia is a country on the Eastern coast of the Baltic Sea with four different and unique seasons: spring, summer, autumn and winter. Latvia is a small country in terms of population with less than two million people in 2016. Latvia has the external European Union border with Russia and Belarus. Most incoming international tourists arrive from Lithuania, Estonia, Russia, Finland and Germany. [11]. In Latvia there are four national parks, which are located in different regions of the country. Gauja National Park (GNP) is the oldest national park in 
Latvia located close to the capital city Rīga. The major and dominant part of the national park is the old valley of the Gauja River. The natural values are geological objects such as caves, cliffs, stones and a high biodiversity of fauna (170 bird species), mammals, flora, cultural heritage objects such as castles, manors and urban planning monuments. The ancient valley of the Gauja River is one of the most significant areas for bat hibernation (including rare bat species) in Latvia. 52 mammal species can be found in GNP, ten of them are included the list of specially protected species [6]. GNP is divided into five zones: strict reserve, nature reserve, cultural historical, landscape protection (the largest area) and neutral.

In 2012 the stakeholders of Gauja National Park established a long-term cooperation in the form of a tourism cluster involving owners of tourism objects, tourism service providers and private, public and educational/research institutions [10]. The goal of the tourism cluster strategy is to achieve the increase in foreign overnight travellers by $20 \%$ in 2020 in comparison with 2012. The visitor, educational awareness and tourism information centres are located inside the national park operated by Nature Conservation Agency of the Republic of Latvia or by local municipalities. The centres are providing tourism and nature interpretation materials on the websites of the centres as well as physically printed materials in the centres, posters and stands in the national park.

In India the majority of protected areas are in the category of national parks. A national park is an area, notified and constituted by the state government for the purpose of its ecological, faunal, floral, geomorphological, or zoological association or importance, needed for protecting and propagating or developing wildlife therein or its environment ENVIS (2017). There are 103 national parks in India covering an area of $40,500 \mathrm{~km} 2$, which is $1.23 \%$ of the geographical area of the country [19]. The KBR is located in the centre of the city of Hyderabad in South India.
The KBR is located in the centre of the city within a densely populated residential and commercial area in the metropolitan city of Hyderabad. The national park is not only a "green lung" for the residents of Hyderabad, but it also acts as a carbon sink and is a vestige of a vast flora, fauna and natural granite rock formations, which represents the Deccan Plateau. The total area of the park is 142.50 ha $(1.42 \mathrm{sq} \mathrm{km})$. There is no open or forest area around KBR National Park and only a width of $25 \mathrm{~m}$ to $35 \mathrm{~m}$ of Hyderabad Metropolitan Development Authority Walkway is available as an open space around the national park [21]. The primary vegetation of the park is that of a tropical dry deciduous type with over 600 plant species and 140 species of birds and 30 different varieties of butterflies and reptiles. Some of the animals making their home in the park include: pangolin, small Indian civet, peacock, jungle cat and porcupines. There are few water bodies present in the park providing the needed moisture for the plants and quenching the thirst of birds and small animals. Open forest and dense scrub dominates the area covering about $45 \%$ of the land, while grasslands and dense forest cover $20 \%$ and $12 \%$ respectively. For convenience, the national park that was earlier used by the citizens of Hyderabad for morning walks and leisure was demarcated into two well defined zones, namely - the Conservation Zone (spanning 88.5ha) and the Visitors Zone (54.0ha) by the State Forest Department. Entry into the former zone is strictly regulated, while the latter zone is open for public on nominal charge. This land was earlier under the control of Nizams of the erstwhile Hyderabad State. The national park has a palace that is the property of the Nizam and is guarded meticulously by a contingent of private security force. The park also has numerous dwelling and non-dwelling units within its boundaries that cover an area of $24,356.02 \mathrm{~m}^{2}$ [13].

\section{DISCUSSIONS AND RESULTS}

The comparison of both national parks is provided in Table 1.

Table 1.

Comparision of Two Nationals Parks

\begin{tabular}{|l|l|l|}
\hline Component & $\begin{array}{l}\text { India } \\
\text { KBR National Park }\end{array}$ & $\begin{array}{l}\text { Latvia } \\
\text { Gauja National Park }\end{array}$ \\
\hline Location & $\begin{array}{l}\text { Located in the urban area, Hyderabad (around 12 million } \\
\text { inhabitants). }\end{array}$ & $\begin{array}{l}\text { Located in both the urban and rural area, includes four } \\
\text { towns: Sigulda, Césis, Līgatne and a gateway to } \\
\text { Valmiera city. 100 000 people live in GNP. }\end{array}$ \\
\hline $\begin{array}{l}\text { Landscape } \\
\text { (Geographical- } \\
\text { land and water) }\end{array}$ & $\begin{array}{l}\text { There are a few water bodies and natural granite rock } \\
\text { formations, which represent the Deccan Plateau. }\end{array}$ & $\begin{array}{l}\text { The main value of GNP is the River Gauja and its valley. } \\
\text { There are a few lakes, smaller rivers and sandstone and } \\
\text { limestone cliffs, caves. }\end{array}$ \\
\hline Biodiversity & $\begin{array}{l}\text { The primary vegetation of the park is that of a tropical } \\
\text { dry deciduous type with over 600 plant species, 140 } \\
\text { species of birds and 30 different varieties of butterflies } \\
\text { and reptiles. Some of the animals making their home in } \\
\text { the park include: pangolin, small Indian civet, peacock, } \\
\text { jungle cat and porcupines. }\end{array}$ & $\begin{array}{l}\text { p2 species of manmals, 170 bird species and almost 900 } \\
\text { plants. }\end{array}$ \\
\hline $\begin{array}{l}\text { Management of } \\
\text { Tourism }\end{array}$ & $\begin{array}{l}\text { In the national park tourism is managed by the forest } \\
\text { No intervention from Tourism department. }\end{array}$ & $\begin{array}{l}\text { Local municipalities are running tourism information } \\
\text { centres, in some places there are visitor-environment } \\
\text { awareness centres operated by Nature Conservation } \\
\text { Agency. }\end{array}$ \\
\hline
\end{tabular}




\begin{tabular}{|c|c|c|}
\hline & & $\begin{array}{l}\text { An NGO - a tourism cluster has been established } \\
\text { involving } 60 \text { stakeholders. }\end{array}$ \\
\hline $\begin{array}{l}\text { Tourism in the } \\
\text { Park }\end{array}$ & 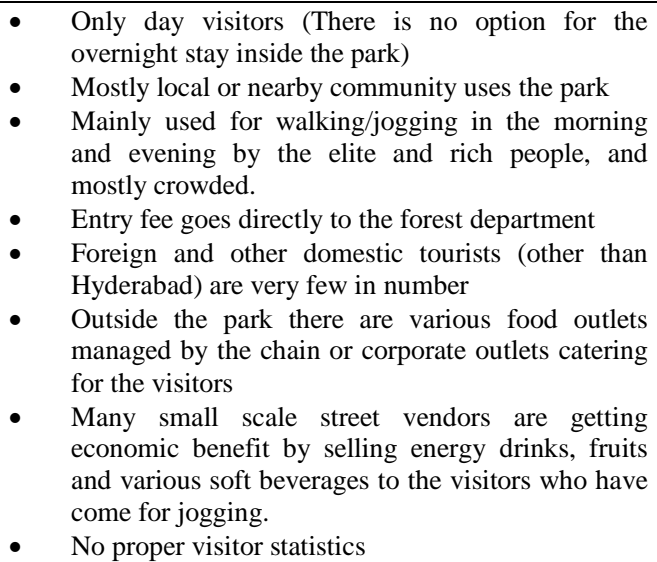 & $\begin{array}{l}\text { - Popular destination for domestic visitors for one } \\
\text { day } \\
\text { - Management focus on the increase of length of the } \\
\text { stay for domestic and international visitors in GNP } \\
\text { - The number of foreign visitors is increasing year } \\
\text { by year } \\
\text { - There is no entrance fee in GNP, but a fee is } \\
\text { charged in specific objects, for example, in a wind } \\
\text { mill, archaeological park. } \\
\text { - Private sector provides catering services and } \\
\text { accommodation in the park mainly operated by } \\
\text { independent companies. } \\
\text { - Craftsmen are active to provide souvenirs and also } \\
\text { to demonstrate skills in interactive workshops for } \\
\text { visitors. } \\
\text { No proper visitor statistics }\end{array}$ \\
\hline Timings & $\begin{array}{l}\text { Entry fee for KBR Park is Rs } 20 / \text { - for adults and Rs10/- } \\
\text { for children (approximately } 28 \text { and } 16 \text { cents) and it is } \\
\text { open } 5: 30 \text { to } 10 \text { am in the morning and } 4 \text { or } 4: 30 \text { to } 7 \\
\text { pm in the evening. }\end{array}$ & No. \\
\hline
\end{tabular}

Local and foreign visitors' survey in GNP in Latvia showed that visitors appreciate untouched nature, especially the foreign guests. $64.3 \%$ of the surveyed foreign visitors find it essential and very important that GNP is a special protection area and has the Natura 2000 label.

For the interest of the administration of GNP, the Latvian respondents also had to answer a question on their support for sports events in the territory of GNP. $82.8 \%$ of all respondents supported the idea, but $9.2 \%$ did not support it. Meanwhile, $8 \%$ of the polled people did not have an answer to this question.

In the survey in KBR National Park visitors were asked questions related to the reasons and habits of visiting the park. The results of KBR National Park Sample Survey show that the main motivation to visit the national park is animal watching (33\%) and ecotourism experience (25\%), but some visitors are less interested in bird-watching and come for just recreation $(12.5 \%)$. The most popular activity in the national park is safari tours $(28.3 \%)$, followed by photography $(23.9 \%)$ while the least popular is workshops (2.2\%) (see Fig.1).

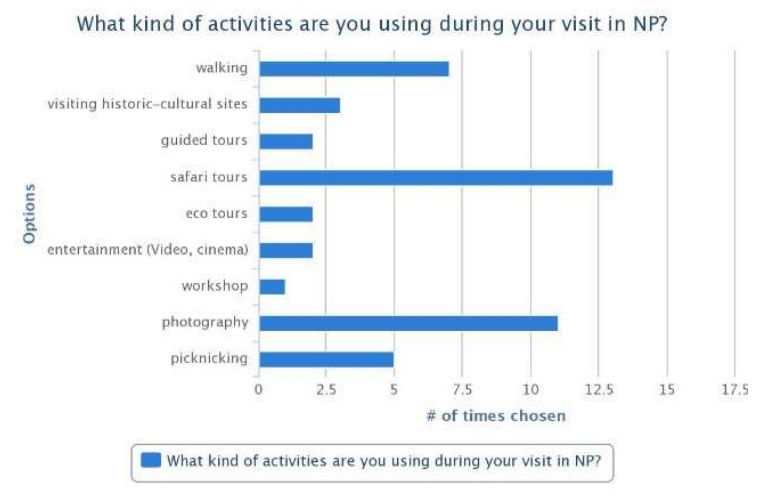

The most often used services and facilities in the national parks are washrooms, catering and information offices. According to Maslow pyramid, the first two facilities mentioned meet the requirement in human basic needs. These are followed by the parking facility and the souvenir service.

Regarding the trail marking, in GNP the answers were different. The national park visitors' survey in India indicated that $42 \%$ do not find walking trail marking important, there are probably the two main reasons for it: the majority of visitors choose safari tours, and as the survey results showed short and medium-length hiking trails up to $3 \mathrm{~km}$ are preferred. In contrast, the trail markings and direction signs are of vital importance in GNP where the tourism infrastructure - marked trails, information signs - is well developed. In some cases in GNP, the reference is made to the lack of information in English.

Most respondents spent between two and six hours in the national parks. Of course, during face-toface interviews the respondents drew attention to the type of the visited national park. We can fully agree that the time visitors spent in the national parks correlates with the qualities of the particular park and the provided tourism infrastructure.

\section{CONCLUSION}

To sum up, this experience of conducting a survey in Hyderabad in India and in Latvia gave the authors a new competence on how to carry out a survey in different countries taking into account intercultural aspects, the choice of words for defining questions and the communication with locals.

Visitors have different expectations during the visits to the national parks. In India the main focus is on watching animals, while in Latvia a greater emphasis is put on walking in nature, underlining the overall importance of the landscape during the park experience. According to visitors' expectations, the tourism infrastructure should be improved in both 
Latvian and Indian national parks, if the park management and tourism destination organizations in the national parks want to position them as a nature tourism offer both in the local and international market. In case of India, there is a particular need to develop tourism information infrastructure (direction signs, maps with routes, sights, interpretive information, including on the landscape and plants, not only animals).

The comparison of nature based tourism in two national parks in Latvia and India highlighted the different approaches of the use of national parks according to visitor purpose, motivation and the nature resources in the national parks; as well as that, the management system of tourism and nature conservation is different not only between the countries, but also within a country.

National parks have a great potential in the tourism offer. Tourism in GNP develops rapidly and it should be taken into account for sustainable tourism planning, directing the flow of visitors to the lesserknown attractions. In case of India, there are unused opportunities in the wider national park positioning in tourism appreciating the national park as a totality of natural and cultural values. There is also a urgent need to change the impression and mindset of the visitors about the national parks, as if they are mainly and particular for popular animal watching, and this can be done through various awareness programs.

\section{ACKNOWLEDGMENTS}

The paper was supported by the National Research Program 5.2. EKOSOC-LV of the Republic of Latvia and European Union ERASMUS + programme.

\section{REFERENCES}

[1] A. Stronza, W. Durham, "Ecotourism and conservation in the Americas", Cambridge, MA: CAB International, 2008.

[2] M. Honey, Ecotourism: Who owns paradise? (2nd ed.). Washington, DC: Island Press, 2008.

[3] J.Higham, Critical issues in eco-tourism: Understanding a complex tourist phenomenon, Oxford: Elsevier. 2007.

[4] C.M. Hall, Tourism Planning Policies, Processes and Relationships. $2^{\text {nd }}$ edition. Pearson Education Limited: England, 2008

[5] D. Weaver, B. Faulkner, L. Lawton, L. "Nature-based tourism in Australia and beyond: Australia and beyond: a preliminary investigation", Work-in-progress, CRC for Sustainable Tourism, 1999.
[6] V. Pilāts. Biodiversity in Gauja National Park. Sigulda, Gauja National Park Administration, Tech.Rep. 2007.

[7] World Health Statistics (WHS) 2016. World Health Organisation.

[8] World Health Statistics (WHS) World Health Organisation. Tech.Rep. PP.155-165, 2013.

[9] R. Mirzaei, "Modelling the Socioeconomic and Environmental Impacts of Nature-Based Tourism to the Host Communities and their Support for Tourism. Perceptions of Local Population: Mazandaran, North of Iran," Licentiate thesis, University of Giessen, 2013.

[10] A. Livina, Dz. Atstaja, Dz., "Understanding the Philosophy and Performance of Tourism and Leisure in Protected Areas for transition to a Green Economy", in Tourism in the Green Economy, (ed. Reddy, M.,V., Wilkes, K.), Routledge, 2015.

[11] I. Druva-Druvaskalne, A. Livinina, A. "Tourism in Latvia: from fragmented resorts of Russian empire to a national brand on international level", in European Tourism Planning and Organisation Systems Volume II. (ed Costa, C., Panyik, E., Buhalis, D.) Channel View, 2015.

[12] F. Giongo, J.Bosco, G.N. Wallace, A Study of Visitor Management in the World's National Parks and Protected Areas. Colorado State University, Fort Collins, Colorado City, USA. 1993.

[13] C. Srinivasulu, B. Srinivasulu, A.Rajesh, C. Rao, V. Nagulu. "Non-volant small mammals of Kasu Brahmananda Reddy National Park, Andhra Pradesh", Zoos' Print Journal, 19 (6), pp.1495-1497, 2004.

[14] J. Deng, B. King, B., \& T.Bauer, T. "Evaluating natural attractions for tourism", Annals of tourism research, 29(2), pp. 422-438. 2002.

[15] I. Druva-Druvaskalne, A. Lìvinia, "Assessment of environmental aspects in rural tourism in two areas of the North Vidzeme Biosphere Reserve", in: Economic, social and cultural aspects in biodiversity conservation (eds. Opermanis, O., Whitelaw, G.), Press of University of Latvia. pp.19-30, 2008

[16] L. Davidson, "On Nature`s Terms: preserving the Practice of traditional Backcountry Recreation in New Zealand's National Parks". In: Intangible natural Heritage New Perspectives on Natural Objects. Ed. Dorfman, E. Routledge, 2012.

[17] S.Wall Reinius, P.Fredman, "Protected areas as attraction", Annals of Tourism Research, Vol. 34, no 4, pp. 839-854, 2007.

[18] P. Fredman and L. Tyrväinen, L. "Frontiers in Nature-Based Tourism", Scandinavian Journal of Hospitality and Tourism, 10 (3), pp.177-189, 2010.

[19] ENVIS. Centre on Wildlife \& Protected Areas. National Wildlife Database. [Online]. April, 2017. Available: http://wiienvis.nic.in/Database/npa_8231.aspx

[20] N. Dudley, "IUCN Guidelines for Applying Protected Area Management Categories", 2008. Available at http://data.iucn.org/dbtw-wpd/edocs/paps-016.pdf

[21] Moef. Minutes of the $7^{\text {th }}$ expert committee, 2017. Available: http://www.moef.gov.in/sites/default/files/MINUTES\%20O F\%2017TH\%20EXPERT\%20COMMITTEE.pdf

[22] UNWTO. "Tourism statistics" [Online], 2017, Available: http://www2.unwto.org 